\title{
Pengaruh Penggunaan Google classroom Terhadap Efektifitas Pembelajaran
}

\author{
The Effect Of The Use Of Google classroom On The Effectiveness \\ Of Learning
}

\author{
Aser Paul Nainggolan, Rizki Bastanta B. Manalu \\ Program Studi Pendidikan Olahraga, Universitas Quality Berasatagi, Jl. Jamin Ginting No. 41, Raya, \\ Kabanjahe, Kabupaten Karo, Sumatera Utara, 22512, Indonesia \\ e-mail : aser.pau10432@gmail.com, bastanta.rizki@gmail.com
}

\begin{abstract}
Abstrak
Google classroom adalah media pembelajaran e-learning dengan menggunakan sistem WebCT. Adanya Google classroom selama masa pandemi Covid-19 ini mampu berfungsi dalam memberikan kemudahan bagi sekolah-sekolah dengan sistem belajar dapat diakses kapan dan dimana saja tanpa harus tertatap muka secara langsung. Penelitian ini bertujuan untuk menganalisis pengaruh penggunaan google classroom terhadap efektifitas pembelajaran di SMP Cahaya Pengharapan Abadi. Subjek dalam penelitian ini yaitu siswa kelas VII dan VIII yang mengikuti mata pelajaran pendidikan jasmani dengan menggunakan google classroom yang berjumlah 31 siswa. Instrument yang digunakan dalam penelitian ini berupa tes belajar dan lembar angket tentang efektifitas pembelajaran dengan alat bantu angket yaitu google form. Analisis data dengan menggunakan regresi linear berganda, kemudian diolah dengan SPSS 18. Hasil penelitian menunjukkan Terdapat hasil positif persepsi kemudahan, kemanfaatan terhadap penggunaan google classroom di SMP Cahaya Pengharapan Abadi dengan nilai R-adjusted sebesar 0.475. Tingkat kemudahan yang diberikan oleh aplikasi google classroom akan memberikan respon yang positif oleh siswa terhadap penggunaan google classroom. Terdapat pengaruh positif dan signifikan kemudahan, kemanfaatan terhadap efektifitas pembelajaran dengan nilai R-adjusted sebesar 0.475 . Artinya kemudahan dalam memanfaatkan google classroom akan mampu menyebabkan efektifitas pembelajaran. Kemudahan menjadikan motivasi bagi siswa untuk terus bersemangat mengikuti pembelajaran. Sedangkan guru mampu memberikan semangat dan dukungan bagi siswa agar tetap belajar walaupun dalam kondisi tidak bertatap muka. Terdapat pengaruh positif dan signifikan penggunaan google classroom terhadap efektifitas pembelajaran dengan nilai sebesar 0.244 .
\end{abstract}

Kata kunci: Google classroom, Efektifitas Pembelajaran

\section{Abstract}

Google classroom is an e-learning media using the WebCT system. The existence of a Google classroom during the Covid19 pandemic was able to function in making it easy for schools with a learning system that could be accessed anytime and anywhere without having to come face to face directly. This study aims to analyze the effect of using google classroom on the effectiveness of learning at Cahaya Pengharapan Abadi Middle School. The subjects in this study were students in grades VII and VIII who took physical education subjects using google classroom, totaling 31 students. The instrument used in this study was a learning test and a questionnaire about the effectiveness of learning with the questionnaire tool, namely the google form. Data analysis used multiple linear regression, then processed with SPSS 18. The results showed that there was a positive result of the perception of ease and benefit for the use of google classroom at SMP Cahaya Pengharapan Abadi with an R-adjusted value of 0.475. The level of convenience provided by the google classroom application will provide a positive response by students to the use of google classroom. There is a positive and significant effect of ease and benefit on the effectiveness of learning with an R-adjusted value of 0.475. This means that the ease of using google classroom will be able to lead to effective learning. The ease of making motivation for students to continue to be enthusiastic about participating in learning. Meanwhile, the teacher is able to provide enthusiasm and support for students to keep learning even when they are not face to face. There is a positive and significant effect of using google classroom on the effectiveness of learning with a value of 0.244 .

Keywords: Google classroom, Learning Effectiveness

corresponding author: aser.pau10432@gmail.com

Artikel Info:

Submitted : 22/02/2021

Revised : :03/03/2021

Accepted : 10/03/2021

Published : 17/05/2021 


\section{A. Pendahuluan}

Teknologi yang semakin mengalami perkembangan mengharuskan seseorang untuk dapat mengadopsi dan menggunakan secara bijaksana. Menurut (Budiman, 2017), bahwa perkembangan teknologi pada era globalisasi menjadi sebuah tantangan dan tidak dapat dihindari termasuk dalam dunia pendidikan. Hal senada diungkapkan oleh (Lestari, 2018), bahwa pemanfaatan teknologi dalam dunia pendidikan membantu dalam proses pembelajaran sebagai sarana dalam mengakses informasi kegiatan pembelajaran dan tugas.

Generasi milenial merupakan generasi terlahir pada era perkembangan teknologi dan informasi yang mengalami perkembangan dengan pesat. Generasi milenial juga disebut sebagai generasi internet booming. Penggunaan teknologi oleh generasi milenial seperti google, youtube, email dan media sosial lainnya. Menurut (Supratman, 2018), menyatakan bahwa internet bagi generasi muda atau disebut digital native merupakan bagian dari kehidupan mereka. Perkembangan usia pengguna internet di Indonesia dapat dilihat pada Gambar 1.

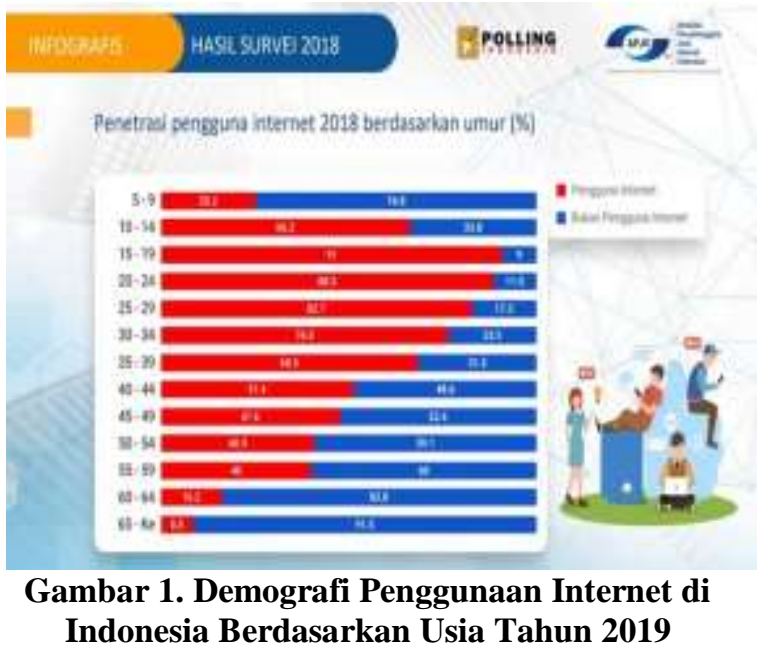

Gambar 1, pengguna internet menurut APJII (Asosiasi Penyelenggara Jasa Internet Indonesia) menunjukkan bahwa berdasarkan usia yaitu 10-14 tahun penggunaan internet sebesar 33,4 persen di Indonesia. Hal ini membuktikan bahwa generasi milenial mengakses internet untuk memperoleh berbagai informasi dengan menggunakan gadget. Dalam dunia pendidikan, perkembangan teknologi juga dampak, hal ini dapat terlihat dari adanya penggunaan e-learning dalam kegiatan pembelajaran di sekolah.

E-learning diartikan sebagai pembelajaran jarak jauh dengan menggunakan akses internet dan perangkat komputer (Setiawardhani, 2013). Dalam penelitiannya penerapan kelas e-learning dan tanpa e-learning, diperoleh hasil lebih baik kelas yang menerapkan e-learning (Hasan, \& Ambarita, 2017). Untuk menghasilkan e-learning yang menarik maka dibutuhkan beberapa kriteria seperti mudah diakses, dipahami dan dipelajari 
(Muhson, 2010).

SMP Cahaya Pengharapan Abadi menerapkan pembelajaran dengan menggunakan e-learning pada masa pandemi Covid-19 saat ini. Google classroom merupakan salah satu bentuk penerapan pembelajaran dengan menggunakan media e-learning . Adapun portal pada google classroom adalah https://classroom.google.com/, yang mana layanan tersebut hanya dapat diakses oleh guru dan siswa pada sekolah tersebut.

Efektifitas pembelajaran dengan google classroom dalam pendidikan, terutama bagi guru sebagai tenaga pendidik mengharuskan untuk dapat memanfaatkan teknologi. Dengan adanya teknologi, guru dapat lebih kreatif dalam menjalankan pembelajaran dengan menggunakan google classroom. Aplikasi google classroom mempunyai kebermanfaatan dalam proses mengajar dikarenakan mampu meningkatkan intensitas pembelajaran secara interaktif dan komunikatif diluar jam belajar yang resmi (Septantiningtyas, 2019).

Pembelajaran dengan menggunakan google classroom menjadi tantangan tersendiri dalam meningkatkan efektifitas pembelajaran siswa. Ini dikarenakan pembelajaran secara daring tidak semua sekolah sebelumnya menerapkan termasuk SMP Cahaya Pengharapan
Abadi. Sehingga peneliti tertarik untuk melakukan penelitian dengan tujuan mengetahui pengaruh penggunaan google classroom terhadap efektifitas pembelajaran di SMP Cahaya Pengharapan Abadi.

Penelitian terdahulu yang dilakukan oleh (Sabran \& Sabara, 2019) dengan judul keefektifan google classroom sebagai media pembelajaran. Hasil penelitian menunjukkan bahwa aspek perencanaan, aspek perancangan, aspek penyampaian materi/materi pembelajaran, aspek interaksi pembelajaran, aspek evaluasi pelaksanaan pembelajaran, merupakan faktor yang mempengaruhi keefektifan e-learning dengan menggunakan google classroom. Selain itu juga terdapat faktor pendukung lainnya seperti sumber daya manusia (SDM), sarana dan prasarana. Disisi lain juga terdapat faktor penghambat seperti motivasi yang masih rendah disebabkan oleh fasilitas (Sabran \& Sabara, 2019).

Penelitian lain juga dilakukan oleh (Mudamayanti \& Wiryanto, 2020) tentang efektifitas penggunaan aplikasi google classroom untuk mengukur pencapaian indikator terhadap pembelajaran matematika materi pengolahan data kelas $\mathrm{V}$ di tengah situasi lockdown akibat virus Covid-19. Ditemukan hasil penelitian bahwa sebagian besar siswa mengikuti 
pembelajaran secara daring lebih tertarik, optimal dan efektif. Ini ditunjukan dengan siswa dapat terampil dalam memanfaatkan teknologi kearah yang positif. Selain itu juga, diperlukan motivasi yang positif agar siswa dapat lebih bersemangat mengikuti pembelajaran, sehingga pada akhirnya akan mampu meningkatkan hasil belajar (Sinuraya, 2018).

Penelitian terdahulu dilakukan oleh (Nirfayanti \& Nurbaeti, 2019) melakukan penelitian dengan judul Pengaruh Media Pembelajaran Google classroom Dalam Pembelajaran Analisis Real Terhadap Motivasi Belajar Mahasiswa. Hasil penelitian menunjukkan bahwa terdapat pengaruh yang signifikan antara media pembelajaran google classroom terhadap hasil belajar. Ini berarti google classroom bermanfaat dalam kegiatan pembelajaran.

Selain itu, pada penelitian yang dilakukan oleh (Sabran \& Sabara, 2019), bahwa aspek yang berpengaruh terhadap keefektifan e-learning dan google classroom terdiri dari aspek perencanaan pembelajaran google classroom, aspek perancangan dan pembuatan materi, aspek penyampaian pembelajaran, aspek interaksi. Sedangkan faktor pendukung yaitu kesiapan SDM untuk meningkatkan pembelajaran, fasilitas software, internet. Sedangkan faktor penghambat yaitu masih kurangnya motivasi untuk pengembangan pembelajaran.

\section{B. Metode Penelitian}

Penelitian ini dilakukan di SMP Cahaya Pengharapan Abadi dengan alamat Jl. Veteran Pasar V Desa Manunggal, Kecamatan Labuhan Deli, Kabupaten Deli Serdang. Penelitian ini dilakukan pada bulan Oktober 2020 sampai dengan November 2020.

Pendekatan kuantitatif digunakan dalam penelitian ini, melalui teknik analisis korelasi. Pengambilan sampel dilakukan secara sensus, artinya seluruh siswa dikelas VII dan VIII di SMP Cahaya Pengharapan Abadi yang mengikuti pembelajaran dengan menggunakan google classroom dengan jumlah subjek penelitian sebanyak 31 orang siswa. Data dikumpulkan dengan menggunakan angket dengan alat bantu google formulir. Adapun kriteria yang digunakan yaitu dengan menggunakan skala likert (Tabel 1).

Tabel 1. Skala Pengukuran Data (Skala likert)

\begin{tabular}{ccc}
\hline No & Uraian & Skor \\
\hline 1. & Sangat Tidak Setuju & 1 \\
2. & Tidak Setuju & 2 \\
3. & Setuju & 3 \\
4. & Sangat Setuju & 4 \\
\hline
\end{tabular}

Sumber: (Arikunto, 2006)

Analisis data secara deskriptif dengan memberikan gambaran mengenai fenomena yang terjadi didalam penelitian. Adapun analisis yang dilakukan yaitu uji kualitas data terdiri dari uji validitas dan uji reabilitas. Uji validitas dan uji reabilitas 
menggunakan SPSS Versi 18. Selanjutnya dilakukan uji asumsi klasik. Pada uji asumsi klasik terdiri dari uji normalitas, uji multikolineritas dan uji heteroskedastisitas. Dan yang terakhir adalah dengan menggunakan regresi linear berganda. Pada uji ini untuk mengetahui pengaruh dari variabel bebas $(\mathrm{X})$ terhadap variabel terikat (Y) (Sugiyono, 2014).

\section{Hasil dan Pembahasan Uji Validitas}

Data yang telah dikumpulkan dengan menggunakan google form, sebelumnya dilakukan uji terhadap kualitas data dari kuesioner sehingga dapat dinyatakan valid. Oleh sebab itu, perlu dilakukan uji reabilitas dan uji validitas. Uji validitas digunakan untuk mengukur data valid, sehingga menghasilkan data yang tepat dan memberikan gambaran topik penelitian yang diamati (Efendi \& Widodo, 2019). Uji validitas terhadap angket penelitian dapat dilihat pada Tabel 2.

Tabel 2. Instument Variabel Pertanyaan

\begin{tabular}{lc}
\hline Variabel & Jumlah \\
\hline Kemudahan (X1) & 5 \\
Kemanfaatan (X2) & 6 \\
Penggunaan (Y1) & 2 \\
Efektifitas pembelajaran (Y2) & 2 \\
\hline \multicolumn{1}{c}{ Total } & 15 \\
\hline
\end{tabular}

Tabel 2 menunjukkan bahwa berdasarkan variabel yang digunakan untuk menjawab permasalahan penelitian meliputi kemudahan (X1), kemanfaatan (X2), penggunaan (Y1) dan efektifitas pembelajaran (Y2) dengan total jumlah pertanyaan yaitu 15 item pertanyaan. Kemudian dilakukan uji validitas dengan SPSS Versi 18 dengan responden sebanyak 30 orang siswa dan 1 orang guru. Maka hasil yang diperoleh yaitu uji validitas instrument berdasarkan perbandingan $r$-hitung dan r-tabel dengan tingkat signifikan sebesar 0,05. Diperoleh hasil sebesar 0,2431. Sehingga disimpulkan bahwa instrument yang digunakan telah valid. Ini dikarenakan pernyataan bahwa jika r-hitung lebih besar dari r-tabel maka data yang diperoleh telah valid dan layak dilanjutkan ketahap berikutnya. Adapun hasil uji validitas instrumen masing-masing variabel dapat dilihat pada tabel 3 .

Tabel 3. Hasil Uji Validitas

\begin{tabular}{cccc}
\hline Item & r-tabel & r-hitung & Keterangan \\
\hline X1.1 & 0,2343 & 0,835 & Valid \\
X1.2 & 0,2343 & 0,805 & Valid \\
X1.3 & 0,2343 & 0,806 & Valid \\
X1.4 & 0,2343 & 0,741 & Valid \\
X1.5 & 0,2343 & 0,781 & Valid \\
X2.1 & 0,2343 & 0,759 & Valid \\
X2.2 & 0,2343 & 0,719 & Valid \\
X2.3 & 0,2343 & 0,754 & Valid \\
X2.4 & 0,2343 & 0,685 & Valid \\
X2.5 & 0,2343 & 0,721 & Valid \\
X2.6 & 0,2343 & 0,858 & Valid \\
Y1.1 & 0,2343 & 0,822 & Valid \\
Y1.2 & 0,2343 & 0,779 & Valid \\
Y2.1 & 0,2343 & 0,753 & Valid \\
Y2.2 & 0,2343 & 0,634 & Valid \\
\hline
\end{tabular}

\section{Uji Reliabilitas}

Uji reliabilitas merupakan tingkat 
konsistensi apabila pengukuran yang dilakukan tes dapat dipercaya dan dilakukan secara berulang-ulang (Efendi \&

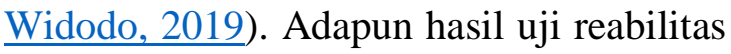
penelitian dapat dilihat pada tabel 4 .

Tabel 4. Hasil Uji Reabilitas

\begin{tabular}{lccc}
\hline Variabel & $\begin{array}{c}\text { Cronbach } \\
\text { 's Alpha. }\end{array}$ & Sig & Ket \\
\hline Kemudahan (X1) & 0,815 & 0,60 & Reliabel \\
Kemanfaatan (X2) & 0,790 & 0,60 & ]Reliabel \\
Penggunaan (Y1) & 0,736 & 0,60 & Reliabel \\
Efektifitas & 0,610 & 0,60 & Reliabel \\
pembelajaran (Y2) & & & \\
\hline
\end{tabular}

\section{Uji Normalitas}

Uji normalitas digunakan untuk menguji sebuah model regresi, variabel penganggu maupun residu yang memiliki distribusi normal. Pengujian normalitas dapat dilihat pada tabel 5 .

Tabel 5. Hasil Uji Normalitas

\begin{tabular}{cccc}
\hline Variabel & $\mathrm{N}$ & $\begin{array}{c}\text { Nilai } \\
\text { Sig. }\end{array}$ & Keterangan \\
\hline $\begin{array}{c}\text { Unstandardized } \\
\text { Residual }\end{array}$ & 31 & 0,211 & Normal \\
\hline
\end{tabular}

Tabel 5 menunjukkan bahwa hasil uji normalitas diketahui bahwa nilai signifikansi sebesar 0,211, sehingga diketahui bahwa data yang digunakan terdistribusi secara normal. Sehingga memenuhi asumsi normalitas karena nilai dari signifikansi alpha 0,05 .

\section{Uji Heterokedesitas}

Gambar 1 merupakan hasil dari Uji Heterokedesitas. Tujuan Uji Heterokedesitas adalah terjadinya ketidaksamaan varian dari residual dalam suatu pengamatan yang lainnya. Jika dilihat pada Gambar 1, maka disimpulkan bahwa pola yang terlihat dari kiri ke kanan pada sebagian dari kelompok tersebut tidak membentuk pola yang sama. Sehingga tidak terjadi masalah dalam heterokedesitas regresi pada penelitian ini.

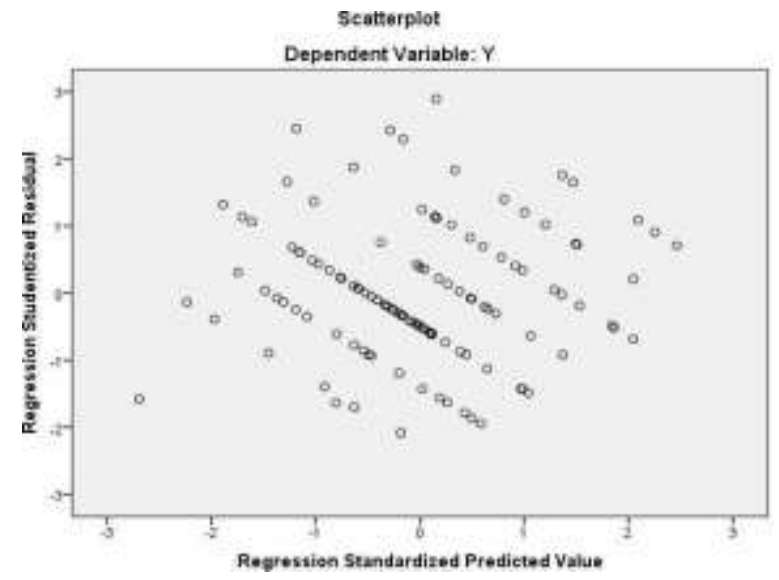

Gambar 1. Hasil Uji Heterokedesitas

\section{Uji Multikolinearitas}

Uji Multikolinearitas dilakukan untuk menguji adanya korelasi antar variabel independen. Berdasarkan hasil uji multikolinearitas disimpulkan bahwa tidak terdapat multikolinearitas pada data. Dimana nilai yang diperoleh yaitu VIF $<10$ dan nilai tolerance $>0,10$.

\section{Tabel 6. Hasil Uji Multikolinearitas}

\begin{tabular}{lccc}
\hline Variabel & & \multicolumn{2}{c}{ Collinearity Statistics } \\
\cline { 2 - 4 } & & Tolerance & VIF \\
\hline $\begin{array}{l}\text { Kemudahan } \\
\text { classroom (X1) }\end{array}$ & Google & 0,719 & 1,426 \\
$\begin{array}{l}\text { Kemanfaatan } \\
\text { classroom (X2) }\end{array}$ & Google & 0,635 & 1,775 \\
$\begin{array}{l}\text { Penggunaan } \\
\text { classroom (Y1) }\end{array}$ & Google & 1.000 & 1.000 \\
\hline
\end{tabular}




\section{Analisis Regresi}

Analisis regresi diawali dengan melakukan analisis yaitu untuk melihat pengaruh dari kemudahan google classroom, kemanfaatan google classroom terhadap penggunaan google classroom. Berdasarkan hasil pengujian dengan menggunaan SPSS pada tabel 7, diketahui nilai unstandardized coefficients beta sebesar 0.467 dibandingkan dengan signifikansi alpha 0,05. Oleh karena itu, dapat diambil kesimpulan bahwa kemudahan Google classroom berpengaruh positif signifikan terhadap penggunaan Google Classrooom.

Hasil pengujian variabel kemanfaatan google classroom menunjukan nilai unstandardized coefficients beta sebesar 0.257 dibandingkan dengan signifikansi alpha 0,05 , maka signifikan. Oleh karena itu, dapat diambil kesimpulan bahwa kemanfaatan google classroom berpengaruh positif signifikan terhadap penggunaan google classrooom. Menurut (Nirfayanti \& Nurbaeti, 2019) bahwa Google classroom sangat berguna dalam proses pembelajaran. (Hakim \& Mulyapradana, 2020) juga menyatakan bahwa manfaat dari Google classroom ini mahasiswa dimudahkan untuk menyimpan dokumen seperti materi maupun tugas penting yang di kirim lewat Google classroom, sehingga jika mahasiswa belum sempat untuk mencetak dokumen yang diperlukan, mereka dapat mengakses terlebih dahulu melalui classroom nya masing-masing. Adapun hasil uji regresi yang dilakukan untuk melihat model, pada tabel 7.

Tabel 7. Hasil Uji t

\begin{tabular}{|c|c|c|c|c|c|}
\hline \multirow[b]{2}{*}{ Variabel } & \multicolumn{2}{|c|}{$\begin{array}{l}\text { Unstandardized } \\
\text { Coefficients }\end{array}$} & \multirow{2}{*}{$\begin{array}{c}\text { Standardized } \\
\text { Coefficients }\end{array}$} & \multirow[t]{2}{*}{$\mathbf{t}$} & \multirow[t]{2}{*}{ Sig. } \\
\hline & B & Std. Error & & & \\
\hline (Constant) & 0.691 & 0.246 & & 2.442 & 0.016 \\
\hline $\begin{array}{l}\text { Kemudahan Google } \\
\text { classroom }\end{array}$ & 0.467 & 0.069 & 0.487 & 6.299 & 0.000 \\
\hline $\begin{array}{l}\text { Kemanfaatan Google } \\
\text { classroom }\end{array}$ & 0.257 & 0.094 & 0.292 & 3.272 & 0.001 \\
\hline
\end{tabular}

Tabel 7 menunjukkan bahwa berdasarkan pengujian dengan menggunakan SPSS diperoleh hasil pengujian unstandardized coefficients 0,467 lebih besar dari taraf signifikansi $=0,05$, maka signifikan. Sehingga dapat disimpulkan bahwa kemudahan google classroom signifikan dan positif terhadap penggunaan google classroom. Pada hasil uji kemanfaatan google classroom dengan nilai 0,257 diperoleh hasil signifikan. Sehingga kemanfaatan google classroom 
berpengaruh positif terhadap penggunaan google classroom.

Berdasarkan koefisien determinasi $\left(\mathrm{R}^{2}\right)$ diperoleh nilai 0,475 atau sebesar 47,5\%. Sehingga disimpulkan bahwa kemudahan google classroom, kemanfaatan google classroom memiliki pengaruh yang positif terhadap penggunaan google classroom dengan nilai sebesar $47,50 \%$ dan sisanya sebesar $52,5 \%$ diluar model tersebut. Untuk hasil koefisien determinasi dapat dilihat pada Tabel 8.

Tabel 8. Hasil Koefisien Determinasi $\left(\mathbf{R}^{2}\right)$ Kemudahan Google classroom, Kemanfaatan Google classroom Terhadap Penggunaan Google classroom

\begin{tabular}{ccccc}
\hline Model & R & R Square & $\begin{array}{c}\text { Adjusted R } \\
\text { Square }\end{array}$ & $\begin{array}{c}\text { Std. Error of the } \\
\text { Estimate }\end{array}$ \\
\hline 1 & $0.712^{\mathrm{a}}$ & 0.508 & 0.475 & 0.32805 \\
\hline
\end{tabular}

a. Predictors: (Constant), Kemudahan Google classroom, Kemanfaatan Google classroom

b. Dependent Variable: Penggunaan Google classroom

Pada tabel 8, kemudahan google pengguna dilihat dari meningkatnya classroom terhadap penggunaan google produtivitas belajar dan mengajar oleh classroom disimpulkan bahwa terdapat pengaruh yang positif dan signifikan. guru dan siswa, artinya walaupun tidak belajar bertatap muka, tidak menganggu Sehingga dalam kemudahan google classroom selama situasi Covid-19 memudahkan guru untuk memberikan materi pembelajaran. Dimana, guru dapat menyampaikan materi, tugas dan informasi seputar kegiatan pembelajaran melalui media google classroom. Sementara itu, pengaruh dari kemanfaatan terhadap proses pembelajaran disekolah SMP Cahaya Pengharapan Abadi.

Hasil uji yang digunakan untuk mengetahui pengaruh dari efektifitas pembelajaran yang dilihat dari kemudahan google classroom dan kemanfaatan google classroom berdasarkan hasil uji-t dapat dilihat pada tabel 9 .

Tabel 9. Hasil Uji-t Kemudahan Google classroom Terhadap Efektifitas Pembelajaran

\begin{tabular}{|c|c|c|c|c|c|}
\hline \multirow[t]{2}{*}{ Variabel } & \multicolumn{2}{|c|}{$\begin{array}{l}\text { Unstandardized } \\
\text { Coefficients }\end{array}$} & \multirow{2}{*}{$\begin{array}{r}\text { Standardized } \\
\text { Coefficients }\end{array}$} & \multirow{2}{*}{$\mathbf{t}$} & \multirow{2}{*}{ Sig. } \\
\hline & B & Std. Error & & & \\
\hline (Constant) & 0.989 & 0.222 & & 5.148 & 0.000 \\
\hline Kemudahan & 0.172 & 0.059 & 0.234 & 3.015 & 0.003 \\
\hline Kemanfaatan & 0.384 & 0.08 & 0.248 & 2.642 & 0.009 \\
\hline
\end{tabular}

a. Dependent Variable: Efektifitas Pembelajaran Siswa

Tabel 9 menunjukkan bahwa hasil uji parameter yaitu kemudahan google 
classroom sebesar 0,172 berarti hasil positif terhadap penggunaan google classroom. Hasil uji kemanfaatan google classroom dengan nilai 0,384 artinya terdapat pengaruh yang positif dari kemudahan google classroom terhadap efektifitas pembelajaran. Artinya dengan adanya google classroom maka penggunaan google classroom menyebabkan praktis dalam menjalankan tugas. Hasil koefisien determinasi $\left(\mathrm{R}^{2}\right)$ dilihat pada tabel 10 .

Tabel 10. Hasil Koefisiensi Determinasi $\left(\mathbf{R}^{2}\right)$ Kemudahan, Kemanfaatan terhadap Efektifitas Pembelajaran

\begin{tabular}{ccccc}
\hline Model & R & R Square & $\begin{array}{c}\text { Adjusted R } \\
\text { Square }\end{array}$ & $\begin{array}{c}\text { Std. Error of the } \\
\text { Estimate }\end{array}$ \\
\hline 2 & $0.672^{\mathrm{a}}$ & 0.431 & 0.459 & 0.2925 \\
\hline
\end{tabular}

Uji-t pada penggunaan google mengetahui pengaruhnya. Sehingga hasil classroom terhadap efektifitas uji-t dapat dilihat pada tabel 11.

pembelajaran dilakukan pengujian untuk

Tabel 11. Hasil Uji-t Penggunaan Google classroom Terhadap Efektifitas Pembelajaran

\begin{tabular}{lccccr}
\hline \multirow{2}{*}{ Variabel } & \multicolumn{2}{c}{$\begin{array}{c}\text { Unstandardized } \\
\text { Coefficients }\end{array}$} & $\begin{array}{c}\text { Standardized } \\
\text { Coefficients }\end{array}$ & $\mathbf{t}$ & Sig. \\
\cline { 2 - 4 } & $\mathbf{B}$ & Std. Error & & & \\
\hline (Constant) & 1.715 & 0.204 & & 8.423 & 0 \\
\hline Penggunaan & 0.428 & 0.065 & 0.546 & 7.072 & 0
\end{tabular}

Tabel 11 menunjukkan bahwa hasil uji parameter yaitu penggunaan google classroom sebesar 0,428 berarti hasil positif terhadap efektifitas pembelajaran. Hasil koefisien determinasi $\left(\mathrm{R}^{2}\right)$ dilihat pada tabel 12 .

\section{Tabel 12. Hasil Koefisien Determinasi $\left(\mathbf{R}^{2}\right)$ Penggunaan Google classroom Terhadap} Efektifitas Pembelajaran

\begin{tabular}{ccccc}
\hline Model & R & R Square & $\begin{array}{c}\text { Adjusted R } \\
\text { Square }\end{array}$ & $\begin{array}{c}\text { Std. Error of the } \\
\text { Estimate }\end{array}$ \\
\hline 3 & $0.546^{\mathrm{a}}$ & 0.268 & 0.244 & 0.32821 \\
\hline
\end{tabular}

a. Predictors: (Constant), Penggunaan Google classroom

b. Dependent Variable: Efektifitas Pembelajaran

Hasil analisis SPSS model summary menunjukkan bahwa Adjusted R-Square sebesar 0,244 atau sebesar $24,4 \%$. Sehingga dapat diartikan bahwa penggunaan google classroom berpengaruh terhadap efektifitas pembelajaran di SMP Cahaya Pengharapan Abadi. Penggunaan google classroom pada 
situasi Covid-19 ini sangat membantu dalam proses pembelajaran di sekolahsekolah. Menurut (Fitra, Sitorus, Parulian Sinaga, \& Marpaung, 2020), bahwa keuntungan yang diperoleh jika mengikuti pembelajaran secara daring adalah kemandirian dalam belajar. Sedangkan menurut (Bagas Panca Pradana, 2017) dalam pembelajaran dengan menggunakan google classroom, baik siswa atau guru dapat mengumpulkan tugas dan melakukan diskusi mengenai materi belajar dapat dilakukan dimanapun dan kapanpun. Sehingga menyebabkan proses pembelajaran lebih menarik dan efisien dalam melakukan pengelolaan waktu dan siswa tidak memiliki alasan untuk lupa akan tugas yang diberikan oleh guru yang mengajar pada saat tersebut. Adapun kecendrungan nilai yang diperoleh dari keefektifan penggunaan google classroom untuk media pembelajaran dapat disajikan pada tabel 12 .

Tabel 12. Distribusi keefektivan pembelajaran dengan google classroom

\begin{tabular}{lccc}
\hline Interval & $\mathrm{F}$ & $\%$ & Keterangan \\
\hline $207 \leq \mathrm{M} \leq 255$ & 8 & 25.81 & Efektif \\
$159 \leq \mathrm{M} \leq 207$ & 22 & 70.97 & Cukup efektif \\
$111 \leq \mathrm{M} \leq 159$ & 1 & 3.23 & Tidak efektif \\
$63 \leq \mathrm{M} \leq 111$ & 0 & 0.00 & $\begin{array}{c}\text { Sangat tidak } \\
\text { efektif }\end{array}$ \\
\hline Jumlah & 31 & $100 \%$ & \\
\hline
\end{tabular}

Berdasarkan tabel 12 dapat dilihat bahwa keefektifan pembelajaran dengan menggunakan google classroom di SMP Cahaya Pengharapan Abadi termasuk dalam kategori cukup efektif sebanyak 22 siswa (70,97\%). Google classroom bersifat fleksibel artinya kemudahan dalam mengakses bagi siswa dimana saja dan kapan saja. Hanya diperlukan akses internet untuk dapat membuka aplikasi tersebut dan dapat diakses dengan menggunakan smartphone dalam proses pembelajaran oleh siswa. Sehingga dengan pemanfaatan google classroom secara efektif akan memudahkan guru dan siswa dakam berkomunikasi dan saling memberikan atau menerima informasi lebih cepat dan efisien tanpa harus bertatap muka diruang kelas. Dengan demikian, proses pembelajaran akan tetap berlangsung dan semakin efektif.

Keefektifan pembelajaran dari kemudahan penggunaan google classroom jika dilihat dari nilai sebesar 3.015. Ini berarti pembelajaran secara daring tidak menjadi hambatan bagi siswa untuk mengikuti pembelajaran. Melalui google classroom, siswa dapat memperoleh materi, contoh soal dan tugas yang di kirimkan oleh guru. Selain itu, tersedianya ruang untuk berdiskusi memudahkan siswa untuk dapat aktif bertanya jika menemukan persoalan dalam pembelajaran materi yang diberikan. Selain itu, kemudahan aplikasi google classroom untuk sarana pengumpulan tugas yang diberikan dalam proses belajar mengajar, tidak menjadi hambatan. Hal yang senada 
dikatakan oleh (Eliyah, Isnani, \& Utami, 2018) bahwa keefektifan merupakan cara atau usaha dari guru agar diperoleh hasil yang sesuai dengan keinginan. Selain itu, hal yang sama juga diperoleh dari hasil penelitian (Endah Wulantina \& Maskar, 2019) menunjukkan bahwa melalui pembelajaran dengan google classroom membuat pembelajran menjadi lebih efektif, pembelajaran blending e-learning berbasis website lebih efektif jika dibandingkan dengan konvensional.

Kemanfaatan google classroom jika dilihat dari hasil uji t sebesar 2.642. maka google classroom memiliki kemanfaatan terhadap efektifitas pembelajaran. Melalui penggunaan google classroom, maka dapat meningkatkan produktivitas belajar dan mengajar sehingga google classroom cukup efektif dalam proses pembelajaran di SMP Cahaya Pengharapan Abadi. Adapun persepsi kemanfaatan yaitu jika individu dalam menggunakan suatu teknologi akan mampu meningkatkan kinerja terutama bagi siswa dalam proses belajar mengajar.

\section{Kesimpulan}

Hasil analisis data yang dilakukan, maka diperoleh kesimpulan yaitu terdapat hasil positif persepsi kemudahan, kemanfaatan terhadap penggunaan google classroom di SMP Cahaya Pengharapan
Abadi dengan nilai R-adjusted sebesar 0.475. tingkat kemudahan yang diberikan oleh aplikasi google classroom akan memberikan respon yang positif oleh siswa terhadap penggunaan google classroom. Begitu pula dengan kemanfaatan terhadap penggunaan, artinya manfaat atau dampak dari penggunaan google classroom disukai oleh siswa, sangat membantu dalam berdisikusi pada guru yang mengajar.

Hasil penelitian terdapat pengaruh positif dan signifikan kemudahan, kemanfaatan terhadap efektifitas pembelajaran dengan nilai R-adjusted sebesar 0.475 . Artinya kemudahan dalam memanfaatkan google classroom akan mampu menyebabkan efektifitas pembelajaran. Kemudahan menjadikan motivasi bagi siswa untuk terus bersemangat mengikuti pembelajaran. Sedangkan guru mampu memberikan semangat dan dukungan bagi siswa agar tetap belajar walaupun dalam kondisi tidak bertatap muka.

Hasil penelitian terdapat pengaruh positif dan signifikan penggunaan google classroom terhadap efektifitas pembelajaran dengan nilai sebesar 0.244. Artinya jika penggunaan terhadap google classroom meningkat akan berdampak pada peningkatan efektifitas pembelajaran. 


\section{Daftar pustaka}

Ambarita, A, M., Hasan, S., \& Ambarita, A. (2017). Penggunaan Model Elearning Dalam Meningkatkan Hasil Belajar Mahasiswa Pada Materi Microprocessor. IJIS - Indonesian Journal On Information System. Https://Doi.Org/10.36549/Ijis.V2i1.2 $\underline{6}$

Arikunto, S. (2006). Data Penelitian Deskriptif. Management Penelitian Analisis.

Bagas Panca Pradana, D. (2017). Pengaruh Penerapan Tools Google classroom Pada Model Pembelajaran Project Based Learning Terhadap Hasil Belajar Siswa. IT-EDU.

Budiman, H. (2017). Peran Teknologi Informasi Dan Komunikasi Dalam Pendidikan. Al-Tadzkiyyah: Jurnal Pendidikan Islam.

Https://Doi.Org/10.24042/Atjpi.V8i1. $\underline{2095}$

Efendi, Y., \& Widodo, A. (2019). Uji Validitas Dan Reliabilitas Instrumen Tes Shooting Sepak Bola Pada Pemain Tim Persiwu Fc Jatiyoso. Jurnal Kesehatan Olahraga.

Eliyah, S., Isnani, \& Utami, W. B. (2018).
Keefektifan Model Pembelajaran Course Review Horay Berbantuan Power Point. Jes-Mat.

Endah Wulantina, \& Maskar, S. (2019). Development Of Mathematics Teaching Material Based On Lampungnese Ethomathematics. Edumatica: Jurnal Pendidikan Matematika.

Https://Doi.Org/10.22437/Edumatica. $\underline{\text { V9i02.7493 }}$

Fitra, A., Sitorus, M., Parulian Sinaga, D. C., \& Marpaung, E. A. P. (2020). Pemanfaatan Dan Pengelolaan Google classroom Sebagai Media Pembelajaran Dan Pengajaran Daring Bagi Guru-Guru SMP. Jurnal Pengabdi.

Https://Doi.Org/10.26418/Jplp2km.V $\underline{3 i 2.42387}$

Hakim, M., \& Mulyapradana, A. (2020). Pengaruh Penggunaan Media Daring Dan Motivasi Belajar Terhadap Kepuasan Mahasiswa Pada Saat Pandemik Covid-19. Widya Cipta: Jurnal Sekretari Dan Manajemen. Https://Doi.Org/10.31294/Widyacipta . $\mathrm{V} 4 \mathrm{i} 2.8853$

Lestari, S. (2018). Peran Teknologi Dalam Pendidikan Di Era Globalisasi. http://ejurnal.ubharajaya.ac.id/index.php/JCESPORTS 
Edureligia; Jurnal Pendidikan Agama

Islam.

Https://Doi.Org/10.33650/Edureligia. $\underline{\mathrm{V} 2 \mathrm{i} 2.459}$

Mudamayanti, P., \& Wiryanto. (2020). Efektifitas Penggunaan Aplikasi Google classroom Untuk Mengukurpencapaian Indikator Terhadap Pembelajaran Matematika Materi Pengolahan Data Kelas V SD

Di Tengah Situasi Lockdown Akibat Virus Covid-19. Jurnal Ilmu Pendidikan PGSD.

Muhson, A. (2010). Pengembangan Media Pembelajaran Berbasis Teknologi Informasi. Jurnal Pendidikan Akuntansi Indonesia. Https://Doi.Org/10.21831/Jpai.V8i2.9 $\underline{49}$

Nirfayanti, N., \& Nurbaeti, N. (2019a). Pengaruh Media Pembelajaran Google classroom Dalam Pembelajaran Analisis Real Terhadap Motivasi Belajar Mahasiswa. Proximal Jurnal Penelitian Matematika Dan Pendidikan Matematika ISSN 26158132 (Cetak) ISSN 26157667 (Online).

Nirfayanti, N., \& Nurbaeti, N. (2019).
Pengaruh Media Pembelajaran Google classroom Dalam Pembelajaran Analisis Real Terhadap Motivasi Belajar Mahasiswa. Proximal.

Https://Doi.Org/Https://Doi.Org/10.3 $\underline{0605 / 2615-7667.211}$

Sabran, \& Sabara, E. (2019). Keefektifan Google classroom Sebagai Media Pembelajaran. Prosiding Seminar Nasional Lembaga Penelitian Universitas Negeri Makasar.

Septantiningtyas, N (2019). Pengembangan Desain Pembelajaran Pada Kelas Profesional PGMI Google classroom. Edudeena.

Setiawardhani, R. T. (2013). Pembelajaran Elektornik (E-learning ) Dan Internet Dalam Rangka Mengoptimalkan Kreativitas Belajar Siswa. Jurnal Ilmiah Pendidikan Ekonomi Unswagati.

Sinuraya, J. F. (2018). Hubungan Motivasi Dan Hasil Belajar Pada Materi Passing Bawah Bola Voli Menggunakan Model Pembelajran Kooperatif Tipe STAD. Jurnal Penelitian Bidang Pendidikan. 
Sugiyono. (2014). Metode Penelitian Supratman, L. P. (2018). Penggunaan

Pendidikan Pendekatan Kuantitatif,

Media Sosial Oleh Digital Native.

Kualitatif Dan R\&D. In Metode

Jurnal ILMU KOMUNIKASI.

Penelitian Ilmiah.

Https://Doi.Org/10.24002/Jik.V15i1.1 